$ノ-卜$

\title{
亜鉛板上のタンニン酸化成処理皮膜構造の 赤外スペクトルおよび計算化学による研究
}

\author{
植松＼cjkstart崇*，鈴木＼cjkstart雅干*，渡部＼cjkstart修* \\ *福島県ハイテクプラザ(テ 963-0215＼cjkstart福島県郡山市待池台 1-12)
}

\begin{abstract}
Structure of Chemical Coating of Tannic Acid on Zinc Plate Studied by Infrared Spectroscopy and Computational Chemistry
\end{abstract}

Takashi UEMATSU*, Masakazu SUZUKI* and Osamu WATANABE*

*Fukushima Technology Center(1-12, Machiikedai, Koriyama-shi, Fukushima 963-0215)

\begin{abstract}
The structure of a coating film of tannic acid on a zinc plate was studied by infrared reflection absorption spectroscopy and quantum chemistry calculation. It was shown that the film consisted of chelate complexes of zinc (II) and tannic acid.
\end{abstract}

Keywords : Tannic Acid, Chemical Coating, Chelate, Computational Chemistry, Infrared Spectra

\section{1. 緒言}

従来，自動車，家電，建材などに広く利用される覀鉛めつ き部材には，白錆防止用処理として六価クロムを用いたクロ メート処理が施されてきた。しかし，近年，六価クロムが有 する有害性が問題視され，欧州を中心に規制が進んだため， 代替処理の研究開発が活発に行われるようになっている。

クロメート代替処理として, 三価クロム, クロム類似金属, 希土類元素，シリカおよびタンニン酸などの系が多数検討さ れている。中でも，三価クロム化成処理は，現在，有色ク口 メートに並ぶ特性の皮膜が得られるまでになり，代替処理の 主流となっている1)。一方で，三価クロムは環境によっては 六価クロムに変化し得るため, 完全なクロムフリー化が今後 の重要な課題となっている。

タンニン酸は, 植物の樹皮から採取される天然ポリフェ ノール化合物であり, 亜鉛表面に反応し, 防錆効果のある皮 膜を形成することが報告されている2。以来，工業的利用に 向けた検討が多数行われている3 ${ }^{3)}$ 。しかしながら, 皮膜の形 成理由においては，Zn(II)とのキレート結合を介したタン ニン酸の架橋モデル(キレートモデル)が提案されているもの の), 分析の困難さもあり, 詳細に検討した例は見られず, 皮膜構造に関する知見が不十分となっている。

本研究では, タンニン酸化成処理皮膜の構造を考察するた め, まず, 皮膜の赤外分光分析 (FT-IR)を行い, 皮膜形成で タンニン酸の赤外スペクトルに現れる変化に着目した。次い で, 計算化学により皮膜構造を考察した。ここでは, 計算に 用いる皮膜構造モデルとして, 従来から予想されているキ レートモデルを用い, これを検証した。また, 計算結果の解 析から，赤外スペクトルに現れた変化についても考察した。

\section{2. 実験方法}

タンニン酸化成処理皮膜は, 表面に鏡面研磨を施した亜鉛 板 (純度 $99.9 \%, 1 \times 2 \mathrm{~cm}$ ) を基材とし，希酸で洗浄し水洗し た後, $0.5 \mathrm{wt} \%$ タンニン酸 (和光純薬工業(侏)) 水溶液に 1 分間 浸漬し，水洗・乾燥して作製した。

赤外分光分析には, フーリエ変換赤外分光光度計(サーモ エレクトロン(侏)を用い，顕微反射法により測定した。

量子化学計算では, タンニン酸は分子量が大き過ぎるため, キレートモデルにおいて結合に関与するガロイル基にのみ着 目し, 没食子酸メチルを代替モデル化合物として用いた。没 食子酸メチルおよび $\mathrm{Zn}(\mathrm{II})$ に没食子酸メチルが二座で配位 したキレート錯体について, それぞれ分子構造最適化と振動 数計算を, Gaussian 035) を用い, B $3 \mathrm{LYP} / 6-31 \mathrm{G}+(\mathrm{d}) レ$ ベルで行った。図 1 に, タンニン酸, 没食子酸メチルおよび

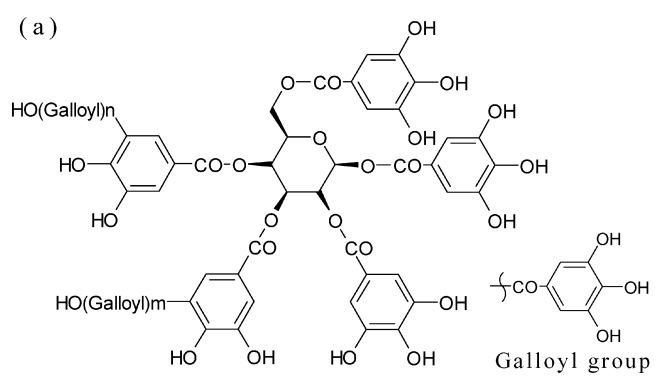

(b)

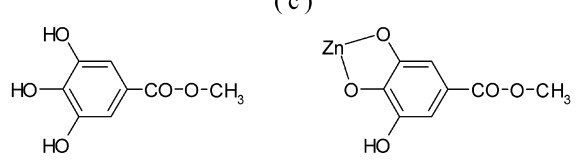

Fig. 1 Molecular structures of (a) tannic acid, (b) methylgallate and (c) zinc (II) methylgallate chelate complex. 
Zn (II) に没食子酸メチルが二座で配位したキレート錯体の 構造式を示す。

\section{3. 結果と考察}

図 2 に, 皮膜を形成する前後のタンニン酸の赤外スペクト ルを示す。図中， $\mathrm{C}=\mathrm{O}$ 伸縮振動，ベンゼン環伸縮振動， $\mathrm{O}$ $\mathrm{H}$ 変角振動および C-O 伸縮振動などの吸収帯が確認される。 皮膜形成により， $\mathrm{C}=\mathrm{O}$ 伸縮振動およびベンゼン環伸縮振動 の吸収帯には，波数シフトが，また幅広の $\mathrm{O}-\mathrm{H}$ 変角振動吸 収帯には，ピーク形状の変化が認められた。中でも，ベンゼ ン環伸縮振動吸収帯は, 皮膜形成前後で, それぞれ 1613, 1534, $1446 \mathrm{~cm}^{-1}$ から，1569，1488，1430 cm-1 にすべて低 波数シフトし，最も顕著な変化を示した。これらは，いずれ も皮膜形成に伴うタンニン酸の構造変化を反映した情報と考 えられる。ここでは，これらを基に，計算化学により皮膜構 造について考察を行った。その際, 検証するモデルには, キ レートモデルを用いた。

まず，分子量の大きいタンニン酸の代替として没食子酸メ チルを計算に用いることが適当であるか，実際に化成処理皮 膜を作製し検討した。皮膜形成前後の没食子酸メチルの赤外 分光分析を行ったところ，ベンゼン環伸縮振動の吸収帯は， 1611，1532，1463 cm-1 から，それぞれ 1561，1482，1422 $\mathrm{cm}^{-1}$ に，タンニン酸と同じく，顕著な低波数シフトを示す ことが確認されたことから, これをモデル化合物として計算 することとした。

図 3 に，計算化学により，没食子酸メチルおよび $\mathrm{Zn}$ (II) と没食子酸メチルのキレート錯体について，それぞれ分子構 造最適化し，振動数計算を行った結果を示す。ただし，振動 数計算では，非調和性が考慮されていないため，計算值は実 験値と比べ高波数側に見られた。図中， $\mathrm{C}=\mathrm{O}$ 伸縮振動，心゙ ンゼン環伸縮振動, C-H 変角振動および $\mathrm{O}-\mathrm{H}$ 変角振動が確 認されるが， $1486 \mathrm{~cm}^{-1}$ の C-H 変角振動は，キレート錯体 ではベンゼン環伸縮振動に重なっている。1763 $\mathrm{cm}^{-1}$ の C= $\mathrm{O}$ 伸縮振動には，実験で認められた低波数シフトは確認され なかったが，これは，実際の皮膜には，計算では考慮されな かった要素が幾つか含まれていることが原因と考えられる。 皮膜形成に関与しているかは明確でないが，例えば，タンニ ン酸の加水分解により生じる没食子酸やその塩，あるいは夕

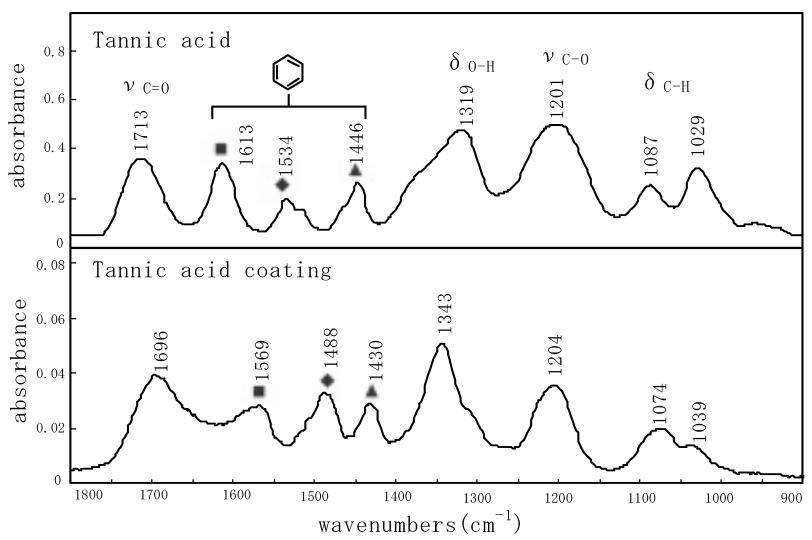

Fig. 2 Infrared spectra of tannic acid and its coating
ンニン酸エステル基の $\mathrm{Zn}$ ( II) への配位などが考えられる。 $1401,1340 \mathrm{~cm}^{-1}$ の $\mathrm{O}-\mathrm{H}$ 変角振動には, 強度減少および低 波数シフトが認められた。これは，計算によると，Zn(II) とキレート結合する水酸基の構造変化にともない，振動モ一 ドが変化したことが原因であるが，実験で認められた変化も， 同じ要因により説明できるものと考えられる。没食子酸メチ

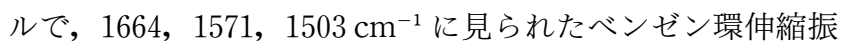
動は，キレート錯体では，それぞれ $1565 ， 1494 ， 1462 \mathrm{~cm}^{-1}$ にあり，すべてに低波数シフトが認められた。これは，実験 事実と同じ顕著な変化であり，キレートモデルが実験事実を よく再現したことを示している。したがって，このモデルが 計算化学により支持されたものと考えられることから, 実際 のタンニン酸化成処理皮膜においても, Zn (II) とタンニン 酸とがキレート結合した化合物が主な構成要素になっている ものと考えられる。

図 4 に, Zn (II) と没食子酸メチルのキレート錯体の最高 被占軌道(HOMO)を計算した結果を示す。図より, HOMO は, ベンゼン環の $\pi$ 軌道を主体とする没食子酸メチルの被 占軌道と, $\mathrm{Zn}(\mathrm{II})$ の $4 \mathrm{~s}$ 空軌道から成っており, これは, 結 合に静電的結合とともに共有結合が働いていることを示して いる。そのため，没食子酸メチルは，キレート形成により $\pi$ 電子が Zn (II)へと流れ込み，ベンゼン環の炭素-炭素結合が 弱くなるものと考えられ，これは，構造計算結果に結合距離 の最大 $3 \%$ の伸びとして認められた。一般に，赤外スペクト

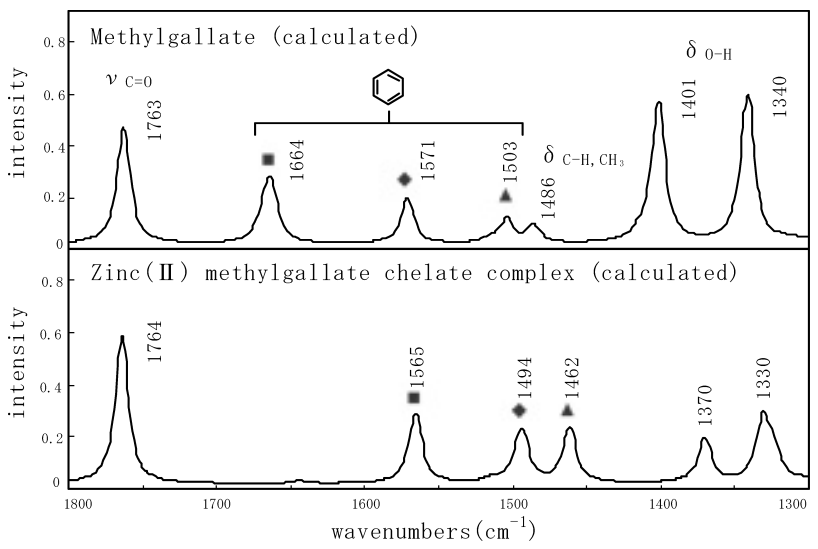

Fig. 3 Calculated Infrared spectra of methylgallate and zinc (II) methylgallate chelate complex.

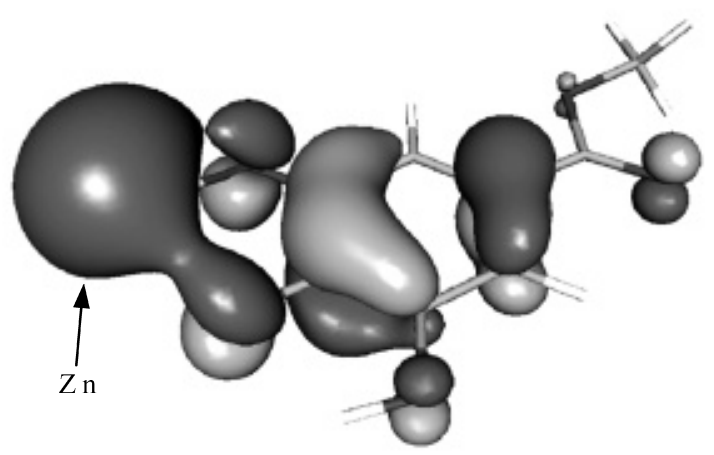

Fig. 4 Highest occupied molecular orbital of zinc(II) methylgallate chelate complex. 
ルにおいて伸縮振動吸収帯の波数は，結合定数を強く反映す ることから，このことが，皮膜の赤外スペクトルにおいて心゙ ンゼン環の伸縮振動に低波数シフトをもたらした要因である と考えられる。

\section{4.まとぬ}

計算化学により, タンニン酸の皮膜形成前後の赤外スペク トルの変化を，キレートモデルがよく再現することが示され た。これにより, タンニン酸化成処理皮膜は, 主にタンニン 酸とZn (II) とがキレート結合した化合物により形成されて いると考察された。また, 計算結果の解析から, 赤外スペク トルのベンゼン環伸縮振動に見られた変化は, ベンゼン環の $\pi$ 電子が Zn (II) に流れ込んだことが要因であることが示さ
れた。

(Received August 31, 2007 ; Accepted October 5, 2007)

\section{文献}

1) Y. Fujiwara and Y. Kobayashi ; J. Surface Finish. Soc. Jpn,, 57, 855 (2006) (in Japanese).

2) T. Watanabe, H. Kawasaki, E. Tarumi and S. Kado ; Kinzoku Hyomen Gijutsu, 29, 38 (1978) (in Japanese).

3 ) O. Watanabe, T. Uematsu, M. Suzuki, T. Utsugi and I. Takahashi; Kobunshi Ronbunshu, 63, 633 (2006) (in Japanese).

4) S. Kado and T. Watanabe; J. Iron Steel Inst., 64, 53 (1978).

5 ）ガウシアン社ホームページ； http：//www.gaussian.com/ citation g 03.htm 